\title{
SOCIAL CHANGE: BULLYING ON BASIC SCHOOL CHILDREN
}

\author{
*Elke Maisyarah \\ Basic Education Study Program, Faculty of Teacher Training and Education \\ Universitas Negeri Padang, Indonesia \\ Email: elke_mai@gmail.com \\ *Corresponding Author, Received: November 12, 2018, Revised: December 10, 2018, Accepted: December 21, 2018
}

\begin{abstract}
Social change is one of the things that is very susceptible to occur in elementery school children. This change occurs due to the child's lack of existing social change. Indeed, this social change that is very vulnerable to occur in children is bullying. Bullying is often found to occur among elementary school children. This certainly must be a concern in the environment of elementary school children can have consequences for children who are bullied. Their children's confidence decreases so that in their environtment he does not feel comfort in him. This article aims to provide solutions related to how to deal with bullying that occurs at school.
\end{abstract}

Keywords: Bullying, Children, Solution

\section{INTRODUCTION}

Social change is one form of problem that is very vulnerable to occur in the elementary school environment. This change is certainly a very important thing to note in order to be overcome. Social change is very bad for children in their environment. One form of existing social change is bullying. We often find bullying in a child's environment. Bullying has a very bad effect on social interactions that occur in children.

Today, bullying has become a habit that exists in children. A researcher and psychological expert states that something that causes bullying is the result of changes that occur in children who are bullying actors. This change must be overcome quickly so that there is no more bullying. Collaboration between teachers and parents is one thing that can be done to prevent bullying itself.

In the last 30 years researchers found that bullying is a form of threat that is very dangerous to children. Bullying is one of the serious threats that results in the 


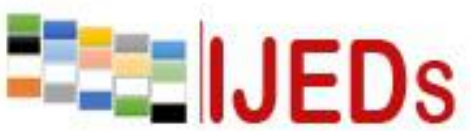

http://ijeds.ppj.unp.ac.id/index.php/IJEDS
International Journal of Educational Dynamics

Vol. 1 No. 1 (pp. 180-187) December 2018

p_ISSN 2655-4852

e ISSN 2655-5093

development of children and the potential causes of violence that occurs in children (Olweus, 1978 in Smokowski and Kopase, 2005). Bullying that occurs in children is considered as one form of violence that occurs in children. So as a result of this bullying, children become antisocial. The child is afraid to socialize with his environment.

Societal fears that occur in children will certainly cause social changes to children's behavior in socializing with their environment. Children who should be able to socialize with confidence and comfort are now a fear in itself because of bullying. Children prefer themselves to playing with friends because they are afraid of being victims of bullying. Its development has also been hampered. Teachers and parents are one of the individuals who are able to prevent bullying that occurs at school. Teachers as educators must be able to recognize social changes that occur in children due to this bullying. The change must also be able to be recognized by parents at home when the child is at home. Because in reality, children spend more time at home than at school. Parents as one place for children to express their complaints must be able to provide a sense of comfort and safety. able to feel comfortable, of course children's self-confidence can arise a little with the encouragement and strong motivation of parents. Home, children certainly feel safer and more comfortable if family members support and encourage children in any aspect that is still in a reasonable context and in accordance with.

Teachers as parents for children in school certainly also play an important role in this matter. Teachers as educators can recognize changes that occur in children well. One form of action that can be taken by teachers in overcoming this is by giving more attention to children who are victims of bullying. Children will find a place that is comfortable and safe for themselves to get violence against themselves. However, if the child does not find a place that is comfortable and safe, of course the changes that occur in the child will be very bad due to this bullying. The encouragement and attention given by the teacher can be an arrow for the child to be able to deal with and overcome the bullying that is done to him so that no more bullets are directed at him. 


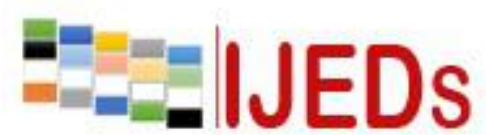

http://ijeds.ppj.unp.ac.id/index.php/IJEDS
International Journal of Educational Dynamics

Vol. 1 No. 1 (pp. 180-187) December 2018

p_ISSN 2655-4852

e_ISSN 2655-5093

\section{METHOD}

There are three important roles that can be a solution in alleviating bullying that occurs in children. The first is, the role of parents. Parents as a family for children must be able to provide a sense of security and comfort for themselves. Children who are bullying desperately need a sense of security and comfort towards themselves. For him to feel that he is indeed protected. In addition, teachers also play an important role in the solution to bullying that occurs in children. Teachers as educators at school, certainly understand the characters that exist in children. By recognizing the character of children, teachers can provide motivation and encouragement to children who are victims of bullying at school. In addition to encouraging children victims of bullying, teachers can also provide a kind of punishment for the perpetrators who bullying their friends. With this punishment, it is considered as a deterrent effect for children in bullying. Thus, the perpetrators of bullying do not dare anymore to bullying their friends who are often victims of bullying itself.

\section{RESULTS AND DISCUSSION}

As explained above, that a problem that is very vulnerable to occurring among elementary school children is bully. From the phenomena that occur in school, of course, it has given us an understanding of how and how the bullying occurred. However, in some times there are those who think that bullying that occurs is not a serious problem. Some people consider that bullying is an exception in cases of violence that occur in children (Omore, 2008). The term "bullying" is used because this word is more representative of all aspects related to bullying. In the use of the word bullying at this time, it means that bullying itself is a deliberate action. This accident results in violence that occurs to someone and is not liked of course.

According to experts on the first definition of bullying in the opinion of (Olweus in Murphy, 2009) which states that a child becomes a victim of bullying if he is negatively repetitive by someone on various occasions. From the explanation of the experts it can be found that this bullying is identical to the negative and occurs repeatedly so that the victims of bullying are afraid and hampered the development of the child. According to Randall (1997) in Randall (2002) that bullying is 


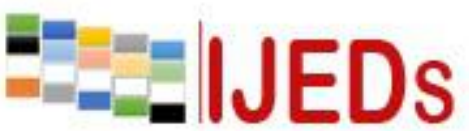

http://ijeds.ppj.unp.ac.id/index.php/IJEDS

intentional aggressive behavior to cause physical and psychological discomfort towards others. This definition emphasizes the motivational factors of bullying actors and provides an overview of the goals behind their behavior. It is very clear that victims of bullying are pressured and given a sense of discomfort physically and psychologically to him. This is one of the reasons why victims of bullying tend to be antisocial. The pressure given is certainly a very frightening thing for children who are victims of bullying. Not only physically, but also psychologically. So sometimes there are children who get certain trauma when he becomes a victim of bullying.

For bullying to change according to the age or school level of children. Sexual violence, physical and psychological assault is one form of crime committed in bullying. This attack was carried out individually or in groups by bullying perpetrators of children who were victims of bullying. Nansel et al in Maliki et al., (2009) state that bullying includes physical bullying (eg hitting, kicking), verbal bullying (for example: mocking, threats) psychological maneuvers (for example: rumors, exclusion) of any kind of harmful behavior or disturbing where the behavior repeats itself at different times and there is an unbalanced force (more powerful people / groups attack someone or groups who lack power).

Usually this bullying tends to occur in children who are fairly fearful. Children who are classified as strong or brave tend to disrupt and suppress fearful children. Children who are victims of bullying have only a few friends. Because, other friends prefer to be friends with friends who are quite powerful. Bullying that occurs can also be in the form of direct bullying. Where, children are often ridiculed by their friends both in class and in the school environment. The other forms of direct bullying are punches. The blows carried out by a child against corruption are certainly a violence committed in the environment.

Other bullying is social. Where one form of social dissatisfaction is bullying that is carried out on the existing internet media. Like on social media. At this time, children tend to use social media in their lives. So, social media becomes a forum for perpetrators bullying to carry out bullying against his friend. One example of bulyying that occurs on social media is showing photos that are considered to make children who are victims of bullying embarrassed. With scattered sikorban photos, of course children 


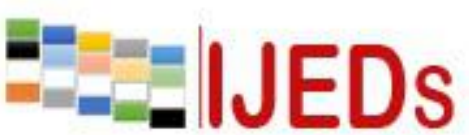

http://ijeds.ppj.unp.ac.id/index.php/IJEDS
International Journal of Educational Dynamics

Vol. 1 No. 1 (pp. 180-187) December 2018

p_ISSN 2655-4852

e ISSN 2655-5093

who are victims of bullying feel embarrassed. Thus, bullying that occurs is very influential on the social change of children who are timid and do not feel comfortable in their environment.

The first characteristic is that children have passive and submissive personality types. These children tend to not be able to defend themselves and their rights. The second characteristic is that children who are victims of bullying tend to have anxiety, nervousness, or insecurity. They also tend to be shy and quiet children. Other characteristics that are typical of victims of bullying are different looks and habits. With these differences, bullying occurs among children. Children who are victims of bullying tend to be frivolous, quiet and don't have many friends. Children like this are very vulnerable to being bullied by friends - his friend. When this happens of course one solution is with the help of the teacher.

The teacher as an educator, as a parent and as the most comfortable place for children must be able to provide a sense of security and comfort that is not obtained by him in the environment with his friends. In addition to the security and comfort provided by the teacher, the motivation and encouragement that exists is also a factor for a child victim of bullying to survive and may be able to fight against bullying done to him. Thus, children do not feel afraid anymore and have confidence in themselves in their environment.

According to The National School Savety Center (NSSC), USA, it is usually excessive to be aggressive, destructive and enjoy their dominance over other children (Carney and Merrell, 2001; NSSC 1995 in Kopasz, 2005). They also tend to be easily offended, explosive and have low tolerance (Olweus, 1993 in Smokowski and Kopasz, 2005). They tend to have difficulties in processing social information so often mistakenly interpret their friends' behavior as a form of hostile behavior directed at their friends itself is a victim of bullying (Dodge, 1991; McNamara \& McNamara, 1997 in Smokowski and Kopasz, 2005). The characteristics of bullying are usually children who like to fight and accentuate themselves in negative terms. Children who are bullying actors are usually feared by friends. So children who are bullying tend to have many friends. Teachers as educators as well as parents at school must be able to overcome and educate children who are bullying actors with a little firm and hard. Because, usually 


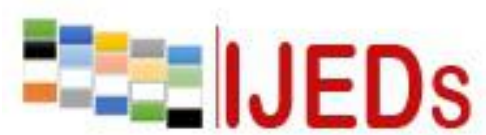

http://ijeds.ppj.unp.ac.id/index.php/IJEDS

\section{International Journal of Educational Dynamics}

Vol. 1 No. 1 (pp. 180-187) December 2018

p_ISSN 2655-4852

e ISSN 2655-5093

children who are bullying are children who are classified as naughty. There needs to be a strong punishment on children who often bullying their friends. One form of punishment can be ordered by the child who is bullying to make an agreement if he is bullying again so he is willing to be expelled from school if the impact of bullying is already very fatal and negative.

However, if what is done is only a case of mocking, laughing and so on, the teacher can give a light sentence to the perpetrators of bullying. Penalties that are usually given are called to the office and given input to the bullying perpetrators that mocking is one form of crime that is not intentionally committed. With the input from the teacher, it is expected that the child is able to understand the consequences that will occur in the bullying treatment itself.

The impact of this bullying on children who are victims of bullying, one of which is the obstruction of children's self development. Developments that should continue to increase, remain due to bullying. Children who are victims of bullying tend to be depressed in their daily activities. So, children do not have the passion to do activities with enthusiasm. Another form of impact that is caused by bullying is the occurrence of depression in children. This depression is a form of psychological pressure. Because the chest pressure which is a problem in the child's psychological make the child feel disturbed in his mind so that the child is depressed. Children who are depressed due to bullying sometimes they make suicide attempts. This certainly becomes a very fatal impact bullying itself. A person's soul can be lost in vain because of the bullying aimed at him.

One example of a bullying case is a shooting case that occurred in a school in the area of Littleton, Corolla, USA on April 20, 1999, where this incident still caused trauma inherent in the community as a result of this incident). In another case of shooting, someone fired on a 14-year-old boy in the playground. Severe psychological disorders in children occur in witnessing this event. Children who have severe disorders are certainly children who have familiarity with victims. It can be concluded that events involving elements of violence both physically and physically can result in deep emotional wounds for individuals who related. 


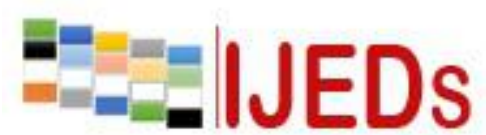

http://ijeds.ppj.unp.ac.id/index.php/IJEDS

\section{International Journal of Educational Dynamics}

Vol. 1 No. 1 (pp. 180-187) December 2018

p_ISSN 2655-4852

e ISSN 2655-5093

In cases of bullying in line with the negative treatment that continues continuously has a very negative effect as well as the emergence of a sense of anxiety that is very deep and experiencing decline in learning ability because he has difficulty concentrating on the consequences of bullying that occurs. In addition to deep depression, another impact caused by bullying behavior on children is the loss of self-confidence, a sense of security and comfort in the environment. This is certainly one of the things that have a very bad impact on children who are victims of bullying. Anxiety and fear are also a visible impact for children of bullying perpetrators in the environment. Therefore, why bullying has a very bad impact on children.

\section{CONCLUSION}

From the discussion conducted, it can be seen that one form of social change that often occurs in the school environment is bullying. Bullying is one form of crime that is usually done by children in school. Bullying that occurs certainly has a negative effect and adversely affects children who are victims of bullying. Depression is one form of impact that can occur in children due to bullying. This depression stems from the pressure given by the perpetrators of the victims of bullying. Thus, the psychological consequences of bullying victims are disrupted. Another form of impact that occurs on bullying is suicide attempts against children who are victims of bullying. Of course this is a very fatal impact and is detrimental to all that is related to this. To overcome the bullying treatment in the school environment, it is necessary to observe and pay attention to teachers, parents and the community environment regarding efforts to overcome the bullying that occurs in the school environment.

\section{REFERENCES}

Randall, 1957. Philpsophy an Intrudction. New York.

Olweus, D. 2007. Always Bullying Questinnare: Standart Scholl Report. Nort America: Hazel Den

Smokowski, P.R. dan Kopasz, H.K. 2005. Bullying in scholl: An Overview of Types, Effects, Family Characteristics and Interfentions Strategies. Children and Scholl, $27(2)$. 
International Journal of Educational Dynamics

$==-=\mid J E D S$

Vol. 1 No. 1 (pp. 180-187) December 2018

p_ISSN 2655-4852

http://ijeds.ppj.unp.ac.id/index.php/IJEDS

e ISSN 2655-5093

O'moore, M. and Minton, S.J. 2004. Dealing with Bullying in Schools: A Training Manual for Teachers, Parents, and Other Professionals. London: Paul Chapman Publishing.

Murphy, A.G. 2009. Character education: Dealing with Bullying. New York: Chelsea House Publisher. 